\title{
Analysis of the Energetic Use of Fuel Fractions Made of Plastic Waste
}

\author{
Halina Marczak ${ }^{1}$ \\ 1 Institute of Transport, Internal Combustion Engines and Ecology, Lublin University of Technology, \\ Nadbystrzycka 36, 20-618 Lublin, Poland \\ e-mail: h.marczak@pollub.pl
}

\begin{abstract}
The overriding principle of waste management (already produced) is their reuse or use as secondary materials. It is consistent with the concept of a circular economy. Recycling materials and raw materials have the highest rank in the field of waste processing. For non-recyclable waste, other recovery processes also play a role. In the case of plastic waste, economically and ecologically justified processes of thermal transformation and catalytic depolymerisation leading to the formation of fuel fractions destined for energetic use may be useful. This direction of polymer waste processing is justified by the high calorific value of plastics. In the objective evaluation of waste treatment technologies, from the point of view of economics and environmental protection, it may be helpful to analyse the energy balance. The aim of the article is to analyse and evaluate the energy efficiency of using a mixture of hydrocarbons obtained in the process of catalytic depolymerisation of plastic waste based on the energy efficiency index for energy purposes. The efficiency index is calculated as the quotient of energy benefits and energy inputs for the use of depolymerisation products. Energy expenditure includes expenditures incurred in individual stages of the life cycle of a liquid product made of plastic waste. The conducted analysis showed that the energy use in the post-use phase of polymer products allows for the recovery of nearly $40 \%$ of the energy required for the production of products and processes enabling the use of waste from these products. Despite the low efficiency index, energy recovery from non-recyclable plastic waste should be considered as a positive action. Plastic packaging waste subjected to catalytic cracking can be included in the settlement of the obligation to achieve the required level of recovery if the cracking products are used for energy purposes.
\end{abstract}

Keywords: management of waste, recovery of plastic waste, waste plastic, energy use of waste, waste processing, depolymerisation of plastic waste.

\section{INTRODUCTION}

In Poland in 2017, 126 million $\mathrm{Mg}$ of waste were generated, including 11,969 million $\mathrm{Mg}$ of municipal waste. Per one inhabitant (with a total population of 37.97 million) there is an average of $315 \mathrm{~kg}$ of municipal waste. 6.8 million $\mathrm{Mg}$ (about 57\%) was recovered, including recycling 3.2 million $\mathrm{Mg}$ (about 27\%), thermal transformation with energy recovery of approx. 2.7 million $\mathrm{Mg}$ (about 23\%), biological transformation 0.848 million $\mathrm{Mg}$ (about 7\%) of municipal waste generated in 2017. 5.2 million Mg (about 43.44\%) were allocated to disposal processes, including about 5 million $\mathrm{Mg}$ (about $41.77 \%$ ) for storage, and 0.2 million $\mathrm{Mg}$ for thermal transformation without energy recovery (approx. 1.67\%) [GUS 2018].

The share of plastics in the morphological composition of municipal waste generated in the country depends on the place of production and is shaped as follows: $15.1 \%$ in large cities (over 50,000 residents, in which $37.18 \%$ of the total population live), $11 \%$ in small towns (less than 50,000 residents, in which $23.89 \%$ of the country's population live) and $10.3 \%$ in rural areas (population constitutes $39.93 \%$ of the total population) [Resolution 2016]. In 2017, 1.478 milion $\mathrm{Mg}$ of plastic waste were produced. In addition, certain quantities of plastics are found in multi-material waste, bulky waste (including furniture, some categories of waste electrical 
and electronic equipment) and in renovation and construction waste.

Proper waste management is supported by selective waste collection, which is currently a statutory obligation for producers of all waste.

In 2017, 295,309 $\mathrm{Mg}$ of plastic waste was selectively collected, which is $8.8 \%$ of the total amount of separately collected municipal waste amounting to $3,239,435 \mathrm{Mg}$ (about $27 \%$ of the amount of municipal waste generated). The amount of plastics waste collected selectively amounts to $7.5 \mathrm{~kg} /$ person/year [GUS 2018]. The data obtained on the selective collection of municipal waste are not yet satisfactory, especially in the view of the requirements to achieve by 31 December 2020 the level of recycling and preparation for re-use of four municipal waste fractions: paper, metals, plastics and glass with a value of at least $50 \%$ of the total mass of these fraction of waste generated in households and by other producers of municipal waste [Regulation 2016]. In 2017 , the weight of waste paper, metals, plastics and glass collected selectively from municipal waste stream amounted to $1,003,840 \mathrm{Mg}$.

From the beginning of 2019, the Regulation of the Minister for Environment [2018] specifies the annual levels of recycling of packaging waste originating from households, which a company dealing with the recovery of this waste should obtain in subsequent years (until 2030) at the achieved recycling levels of packaging waste. For plastic packaging waste, the required recycling level in 2019 is $42 \%$, and in 2030 and in the following years, $60 \%$.

It is the product fee that is to stimulate actions towards the recovery and recycling of packaging waste. It is required from entrepreneurs providing products in packaging, including plastics, for the first time to the domestic market. Entrepreneurs are required to achieve the required annual levels of recycling and recovery of packaging waste. In the case of plastic packaging waste, the obligatory annual recycling level is $23.5 \%$. However, the annual recycling levels of all packages together amount to $56 \%$, and recovery of $61 \%$ [Notice of the Speaker of the Sejm 2019]. If the required levels of recycling and recovery of packaging waste are not met, entrepreneurs or recovery organizations acting on their behalf are required to pay a product fee calculated for not obtaining the required annual recycling level and separately recovering level. To meet these requirements, it is necessary to implement modern waste utilization technologies and improve the organization of the waste management system [Lewandowska and Szulżyk-Cieplak 2018]. In the case of plastic waste, material recycling is the primary objective. The technologies belonging to chemical recycling, e.g. the production of unsaturated polyester resins from PET polymer (polyethylene terephthalate), thermal transformation [Marczak 2014] and catalytic depolymerisation of waste, may also be useful. In the assessment of waste treatment technologies, from an economic and environmental point of view, energy balance analysis may be helpful.

The aim of the article is to analyse and evaluate the energy efficiency of using for energy purposes a mixture of hydrocarbons obtained in the process of catalytic depolymerisation of plastic waste based on the energy efficiency index.

\section{THE PROCESS OF DEPOLYMERISATION OF PLASTIC WASTE AND ITS PRODUCTS}

Depolymerisation of plastic waste is also known as catalytic cracking. It is a process of thermal decomposition of organic compounds (hydrocarbons), with the presence of a catalyst and without air, leading to the production of hydrocarbon products of lower molecular weight, compared to the molecular weight of the feedstock [Matynia 2011].

A valuable raw material for processing in the depolymerisation process are waste plastics from the polyolefin group (polyethylene (PE), polypropylene (PP)) and containing polystyrene (PS). They occur in large quantities in the group of plastic waste, selectively separated from the municipal waste stream. Waste plastics that are not suitable for material recycling can be utilised in this manner. They easily break up at elevated temperatures. As a result of thermal breakdown of polymer chains, a mixture of hydrocarbons in gas form is produced. If the depolymerisation process is carried out at $380-480^{\circ} \mathrm{C}$ and in the presence of a catalyst, the mixture contains hydrocarbons (over $80 \%$ by mass) that can be condensed (boiling point above $40^{\circ} \mathrm{C}$ ). The other components are the gas phase (boiling point below $40^{\circ} \mathrm{C}$ ). Running the process at a higher temperature promotes faster disintegration of the polymer chains, however, it causes a change in the proportions of individual components in the resulting hydrocarbon mixture. 
In an exemplary production process, plastic waste is milled to a fraction of a few millimetres and collected in a tank. A catalyst in the form of a sponge bed of micro-granules covered with aluminium oxides [Matynia 2011] is added to them, after that they are continuously transferred to the reactor. After heating to a temperature of approx. $420^{\circ} \mathrm{C}$ and melting of waste, the polymer chains are torn apart. The decomposition products are hydrocarbons with $\mathrm{C}_{1}-\mathrm{C}_{34}$ carbon atoms. Continuous feeding of waste to the reactor makes the reaction mass consists of non-liquefied, melted waste, gaseous hydrocarbons and liquid hydrocarbons. The mixture of hydrocarbons in the gaseous and liquid phases is directed to the distillation system in which the evaporation takes place, followed by the condensation of its constituents. The role of the cooling medium is filled with water, which is cooled by atmospheric air. Two distillations of gas and liquid products are obtained by distillation. The gas fraction contains $\mathrm{C}_{1}-\mathrm{C}_{4}$ hydrocarbons, liquid fraction: $\mathrm{C}_{5}-\mathrm{C}_{34}$ hydrocarbons. These fractions (at a temperature of about $20^{\circ} \mathrm{C}$ ) are collected in an intermediate tank, from which the gas fraction flows to the gas burner used to heat the reactor, and the liquid fraction to the storage container. Liquid fraction is a commercial product with different application possibilities - as fuel in power boilers and power generators, initiation fuel in power boilers, raw material for processing in refineries (in fractionation distillation or hydrotreating process) to obtain fractions for liquid fuels: gasoline, diesel and heating oil. The elemental composition of the liquid fraction is on average $86 \%$ carbon and $14 \%$ hydrogen.

\section{RESEARCH ASSUMPTIONS AND METHODS}

The research included the determination of the efficiency index for the use of liquid hydrocarbon fraction for energy purposes, obtained as a result of depolymerisation of plastic waste (PE and PP). The Energy Efficiency Index $(E I)$ has been adopted to determine the dependence:

$$
E I=\frac{K_{e}}{N_{e}}
$$

where: $K_{e}$ is energy benefits, expressing the amount of heat obtained from the combustion of a liquid product of depolymerisation of plastic waste $[\mathrm{MJ} / \mathrm{kg}]$,

$N_{e}$ is energy expenditure incurred for the use of plastic waste for energy purposes $[\mathrm{MJ} / \mathrm{kg}]$.

An index value $(E I)$ equal to 1 determines the efficiency boundary. The higher the value of the indicator $(E I)$ than the limit value, the greater the efficiency of waste management solutions. An indicator value $(E I)$ below one means that the solution is inefficient.

The energy benefits were determined by the formula:

$$
K_{e}=W_{o} u_{c}
$$

where: $W_{o}$ is calorific value of liquid product of depolymerisation of plastic waste $[\mathrm{MJ} / \mathrm{kg}]$,

$u_{c}$ is the efficiency of the depolymerisation process (quotient of the amount of liquid fraction and amount of waste material used to produce this amount of liquid fraction) [\% by mass].

The analysis takes into account that as a result of the depolymerisation process from $1 \mathrm{~kg}$ of plastic waste, about $0.82 \mathrm{~kg}$ of liquid hydrocarbon fraction is obtained (about $1 \mathrm{dm}^{3}$, with fraction density $\rho=0.8 \mathrm{~kg} / \mathrm{dm}^{3}$ ) and about $0.18 \mathrm{~kg}$ of hydrocarbon gas fraction [Matuszewski 2012]. The gas fraction is used to heat the reactor in which the process of cracking plastic waste takes place.

The calorific value of depolymerisation products is $43 \mathrm{MJ} / \mathrm{kg}$.

Energy expenditure includes expenditures incurred in individual stages of the life cycle of the raw material under consideration. The considered life-cycle processes for a liquid polymer depolymerisation waste product are shown schematically in Figure 1.

The unit energy expenditure value $\left(N_{e}\right)$ is calculated using the formula:

$$
N_{e}=N_{w}+N_{t 1}+N_{r}+N_{d}+N_{t 2}+N_{s}+N_{t 3}
$$

where: $N_{w}$ is energy inputs for the production of polymers $[\mathrm{MJ} / \mathrm{kg}$, $N_{t 1}$ is energy expenditures for the transport of post-consumer polymer waste to the depolymerisation plant $[\mathrm{MJ} / \mathrm{kg}]$, 


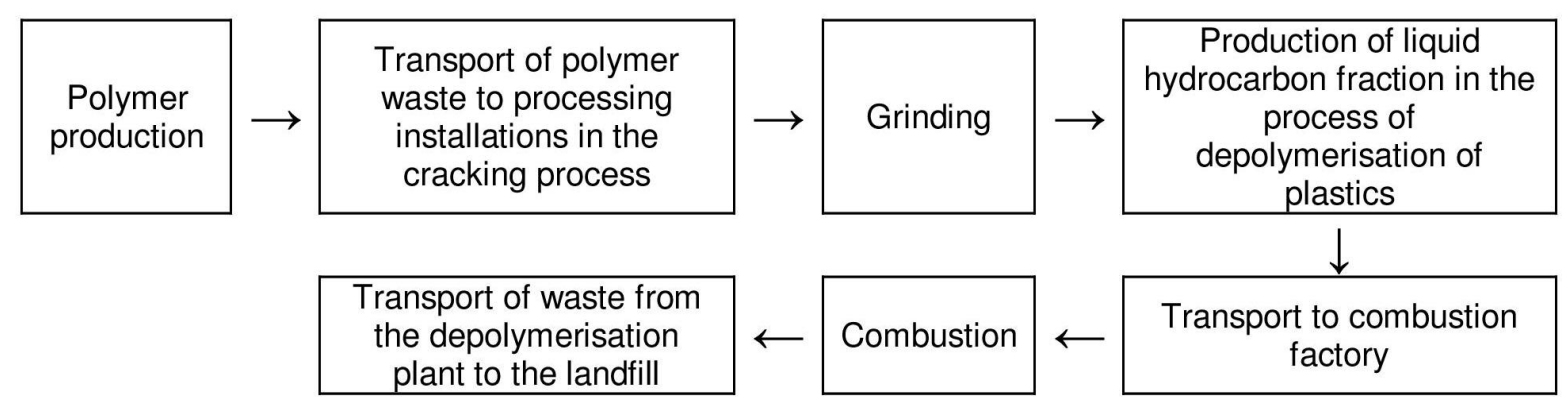

Fig. 1. The main stages of the life cycle of depolymerisation product of polymer waste

$N_{r}$ is energy expenditures for waste milling prior to the depolymerisation process $[\mathrm{MJ} / \mathrm{kg}]$,

$N_{d}$ is energy expenditures incurred in the process of polymer waste depolymerisation $[\mathrm{MJ} / \mathrm{kg}]$,

$N_{\mathrm{t} 2}$ is energy inputs for the transport of liquid depolymerisation product to the combustion plant $[\mathrm{MJ} / \mathrm{kg}]$,

$N_{s}$ is energy expenditure to use (in combustion) liquid hydrocarbon fraction obtained from plastic waste $[\mathrm{MJ} / \mathrm{kg}]$,

$N_{\mathrm{t} 3}$ is energy expenditure on transport of waste from the depolymerisation plant for waste to the landfill $[\mathrm{MJ} / \mathrm{kg}]$.

Calculations of unit energy inputs refer to $1 \mathrm{~kg}$ of feed material to the depolymerisation plant. The stage of polymer production covers all production processes from oil extraction to polymer production. The cumulative demand for energy from non-renewable fuels for the production of selected polymers in Poland is summarized in Table 1. The assessment of non-renewable fuels consumption during polymer production was made using the CED (Cumulative Energy Demand v1.08) method [Goedkoop et al. 2008, VDI 1997]. The data in Table 1 refer to the same functional unit $-1 \mathrm{~kg}$ of polymer.

Table 1. Cumulated energy demand from fuels fossil for the production of polymers in Poland

\begin{tabular}{|c|c|}
\hline Item & Use of fossil resources [MJ/kg] \\
\hline PE & 75.74 \\
\hline PS & 91.55 \\
\hline PP & 88.64 \\
\hline Average (PE, PS and PP) & 85.31 \\
\hline Average (PE and PP) & 82.19 \\
\hline
\end{tabular}

Source: Own elaboration based on Czaplicka-Kolarz et al. [2013].

\section{RESULTS OF CALCULATIONS}

Energy expenditure on the transport of polymeric waste to the processing plant in the depolymerisation process $\left(N_{t 1}\right)$ was determined under the following assumptions:

- transport of waste in compacted (compressed form) in vehicles with a capacity of about $3.5-15 \mathrm{Mg}$ (assumed $12 \mathrm{Mg}$ ),

- average diesel oil consumption at the level of $35 \mathrm{dm}^{3} / 100 \mathrm{~km}$ [Witkiewicz et al. 2018],

- length of the route: $50 \mathrm{~km}$ waste (both ways),

- calorific value of diesel oil equal to $36 \mathrm{MJ} / \mathrm{dm}^{3}$.

The energy needs for the grinding of waste polyolefin plastics were assumed, according to the results of the Scooters survey [2013], at the level of $0.034 \mathrm{MJ} / \mathrm{kg}$. The above-mentioned research concerned the cutting processes of porous polyolefins.

The heat demand in the depolymerisation process of polyolefin plastics was determined based on literature data [Matuszewski 2012]. Heat consumption in the depolymerisation process of waste polyolefin plastics concerns:

- heat taken up by the waste to heat them up to a process temperature of approx. $420^{\circ} \mathrm{C}$ with a value of approx. $1.676 \mathrm{MJ} / \mathrm{kg}(400 \mathrm{kcal} / \mathrm{kg})$,

- heat for liquefaction (melting) of waste with a value of approx. $1.257 \mathrm{MJ} / \mathrm{kg}(300 \mathrm{kcal} / \mathrm{kg})$,

- heat for the transformation of products from the liquid state into a gaseous state of about $1.257 \mathrm{MJ} / \mathrm{kg}(300 \mathrm{kcal} / \mathrm{kg})$.

Additional energy is needed to break the chains of liquid hydrocarbons obtained from the thermodestruction of polyolefin wastes. To determine the value of this energy, the assumption was made that the binding energy $(\mathrm{C}-\mathrm{C})$ is about $0.35 \mathrm{MJ} / \mathrm{mol}$ - providing energy of this value leads to the breaking of a single bond (C-C). It 
has also been taken into account that the mole of the liquid hydrocarbon polymer (before breaking the bonds) has a value approximately equal to the numerical value of the mole of $\mathrm{C}_{71} \mathrm{H}_{144}$. From the additional assumption that the liquid hydrocarbon molecule after decomposition contains 7 carbon atoms results that the base polymer is divided into ten lighter and shorter portions of the polymer chain. Considering the above, a 3.5 $\mathrm{MJ} / \mathrm{kg}$ energy is required for breaking bonds (CC) between the structural unit in the mole of the polymer being processed.

The total energy demand in the depolymerisation process is $7.69 \mathrm{MJ} / \mathrm{kg}$, and taking into account $90 \%$ efficiency of the depolymerisation installation equals $8.544 \mathrm{MJ} / \mathrm{kg}$.

The demand for process heat and energy for the breaking of polymer chains can be significantly covered by the combustion of hydrocarbon gas fraction from waste thermodestruction. The amount of heat recoverable from the gas fraction $\left(Q_{g}\right)$ is determined by the formula:

$$
Q_{g}=W_{o g} u_{g}
$$

where: $W_{o g}$ is calorific value of gaseous product of depolymerisation of plastic waste $[\mathrm{MJ} / \mathrm{kg}]$,

$u_{g}$ is yield of gaseous depolymerisation product [ $\%$ by mass].

The gas fraction is an energy source with a value of $7.74 \mathrm{MJ} / \mathrm{kg}$ (43 MJ/kg $\cdot 0.18 \mathrm{~kg} / \mathrm{kg}$ of feed to the depolymerisation plant). The difference between the thermal needs and the heat gain from the combustion of the gas fraction of 0.854 $\mathrm{MJ} / \mathrm{kg}$ should be covered using an oil burner.

Transporting the liquid depolymerisation product to the combustion installation requires the energy input contained in the transport fuel. The energy input for transport $\left(N_{t 2}\right)$ can be determined using the formula:

$$
N_{t 2}=u_{c} n_{t 2}
$$

where: $u_{c}$ is the yield of liquid depolymerisation product [\% by mass],

$n_{t 2}$ is the energy expenditure on the transport of liquid depolymerisation product $[\mathrm{MJ} / \mathrm{kg}]$.

The energy expenditure on the transport of hydrocarbon liquid fraction was determined under the following assumptions:

- transport of the liquid product is carried out by road tankers with a capacity of approx. $20 \mathrm{Mg}$,
- average diesel consumption of $35 \mathrm{dm}^{3} / 100 \mathrm{~km}$,

- length of the product transport route: $50 \mathrm{~km}$ (both ways),

- energy value of diesel oil $36 \mathrm{MJ} / \mathrm{dm}^{3}$,

- liquid depolymerisation yield of $82 \%$ by mass.

As a result of the calculations, it was obtained that $N_{t 2}=0.026 \mathrm{MJ} / \mathrm{kg}$ of waste processed in the depolymerisation process.

Energy expenditure for the use of a liquid depolymerisation product for energy purposes has been adopted for equal expenditure on the combustion of hard coal in the power plant. The results of the case study were used in the calculations [Kruszelnicka et al. 2018, Spath et al. 1999] in Tables 2 and 3.

The unit energy necessary to use (by burning) the energy (coal) carrier $\left(N_{s}\right)$ was determined from the dependence of:

$$
N_{s}=\frac{n_{p}}{I_{m}}
$$

where: $n_{p}$ is the energy expenditure on energy production; $96.72 \%$ of total energy expenditure was assumed (Table 3 ),

$I_{m}$ is the mass index expressing the mass of carbon in $\mathrm{kg}$ used to generate $1 \mathrm{kWh}$ of energy.

Based on the data presented in Table 2, it was calculated that $I_{m}=2.334 \mathrm{~kg} / \mathrm{kWh}$. The unit energy value $N_{s}$ calculated according to formula (6) is $5.211 \mathrm{MJ} / \mathrm{kg}$.

At the stage of plastic waste preparation for the depolymerisation process, waste is generated, which are small impurities and undesirable components separated from the waste stream constituting the input for this process. In the analysed case, $0.05 \mathrm{~kg}$ of unwanted waste destined for storage falls for $1 \mathrm{~kg}$ of processed waste. The energy expenditure on transport of waste to the landfill $\left(N_{t 3}\right)$ results from the use of transport fuel. Its value was calculated from the formula:

Table 2. Basic technical data for a hard coal power plant

\begin{tabular}{|l|c|c|}
\hline \multicolumn{1}{|c|}{ Parameter } & Units & Value \\
\hline $\begin{array}{l}\text { Effective power } \\
(\mathrm{P})\end{array}$ & MW & 360 \\
\hline $\begin{array}{l}\text { Capacity } \\
\text { utilisation rate (k) }\end{array}$ & $\begin{array}{c}\text { \% of installed } \\
\text { capacity }\end{array}$ & 60 \\
\hline Load capacity (L) & $\mathrm{kg} / \mathrm{d}$ & $3,872,192$ \\
\hline Efficiency ( $\mathrm{\eta})$ & $\%$ & 32 \\
\hline
\end{tabular}

Source: according to Spath et al. [1999]; Kruszelnicka et al. [2018]. 
Table 3. Energy expenditure incurred for the combustion of hard coal in a power plant

\begin{tabular}{|l|c|c|}
\hline \multicolumn{1}{|c|}{ Parametr } & Unit & Value \\
\hline Total energy expenditure to obtain 1 kWh of net electricity $\left(\mathrm{N}_{\mathrm{c}}\right)$ & $\mathrm{MJ} / \mathrm{kWh}$ & 12.5747 \\
\hline Energy expenditure on coal mining $\left(\mathrm{n}_{\mathrm{w}}\right)$ & $\%$ of total expenditure & $1.43 \% \mathrm{~N}_{\mathrm{c}}$ \\
\hline Energy expenditure on transport $\left(\mathrm{n}_{\mathrm{t}}\right)$ & $\%$ of total expenditure & $1.85 \% \mathrm{~N}_{\mathrm{c}}$ \\
\hline Energy expenditure on energy production $\left(\mathrm{n}_{\mathrm{p}}\right)$ & $\%$ of total expenditure & $96.72 \% \mathrm{~N}_{\mathrm{c}}$ \\
\hline
\end{tabular}

Source: own elaboration based on Spath et al. [1999]; Kruszelnicka et al. [2018].

$$
N_{t 3}=u_{z} n_{t z}
$$

where: $u_{z}$ is the share of undesirable components in wastes destined for the depolymerisation process [\% by mass],

$n_{z t}$ is the energy expenditure on transport of waste to the landfill $[\mathrm{MJ} / \mathrm{kg}]$.

The energy expenditure on waste transport $\left(N_{t 3}\right)$ is $0.004 \mathrm{MJ}$ per $1 \mathrm{~kg}$ of waste processed in the depolymerisation plant. This value was calculated on the basis of the following assumptions: transport will be carried out in a vehicle with a capacity of $5 \mathrm{Mg}$, diesel oil consumption by a fully loaded vehicle is $20 \mathrm{dm}^{3} / 100 \mathrm{~km}$, transport distance $50 \mathrm{~km}$ (both ways) and energy value of diesel oil $36 \mathrm{MJ} / \mathrm{dm}^{3}$.

In accordance with the assumptions given in the previous chapter, calculations of energy benefits and energy inputs related to the energy use of polyolefin waste depolymerisation products were made.

The energy benefits from the combustion of the liquid depolymerisation product of polyolefin waste calculated according to formula (2) amount to $35.26 \mathrm{MJ}$ per $1 \mathrm{~kg}$ of waste processed in the depolymerisation process.

The results of calculations of energy inputs are presented in Table 4.

On the basis of equations (1-3), the index of energy efficiency for the use of energy depolymerisation products of polyolefin plastics was determined for energy purposes:

$$
\begin{gathered}
E I=\frac{35.260}{82.190+0.053+0.034+0.854+0.026+5.211+0.004} \\
=0.399
\end{gathered}
$$

The value of the indicator $(E I)$ below one means that the use of depolymerisation products for energy purposes is ineffective.

\section{CONCLUSIONS}

1. The efficiency indicator adopted for consideration may be used to assess the energy and ecological benefits of the waste recovery process consisting in waste cracking and energy use of process products. The value of the efficiency index depends directly on the energy value of waste and inverse in proportion to the energy expenditure incurred for their use by combustion.

2. The amount of energy expenditure depends on the energy efficiency of the processes that make up the life cycle of the product under consideration. The analysis shows energy expenditures on the production of polymers (PE, PP) and expenditures incurred for the combustion of liquid hydrocarbon fraction have a predominant share in energy expenditures for the use of polymer waste for energy purposes.

3 . The obtained research results indicate that energy expenditure on the energy use of the liquid product of depolymerisation of polyolefin waste has an advantage over energy benefits that express the amount of energy released in the form of heat when burning this product.

4. The ecological benefit resulting from the energy use of waste is the reduction of fossil energy resources. Wastes with energy potential that are not suitable for material recycling can replace non-renewable energy carriers. The analysis of

Table 4. Energy expenditure for the use of plastic waste for energy purposes subjected to the depolymerisation process

\begin{tabular}{|c|c|c|c|c|c|c|}
\hline \multicolumn{7}{|c|}{ Energy expenditure [MJ/kg] } \\
\hline $\begin{array}{c}\text { Production of } \\
\text { polymers (PE, PP) }\end{array}$ & $\begin{array}{c}\text { Transport to depo- } \\
\text { lymerisation plant }\end{array}$ & $\begin{array}{c}\text { Waste } \\
\text { grinding }\end{array}$ & $\begin{array}{c}\text { Depolymerisation } \\
\text { process }\end{array}$ & $\begin{array}{c}\text { Transport to } \\
\text { combustion factory }\end{array}$ & Combustion & $\begin{array}{c}\text { Transport } \\
\text { to landfill }\end{array}$ \\
\hline$\left(\mathrm{N}_{\mathrm{w}}\right)$ & $\left(\mathrm{N}_{\mathrm{t} 1}\right)$ & $\left(\mathrm{N}_{\mathrm{r}}\right)$ & $\left(\mathrm{N}_{\mathrm{d}}\right)$ & $\left(\mathrm{N}_{\mathrm{t} 2}\right)$ & $\left(\mathrm{N}_{\mathrm{s}}\right)$ & $\left(\mathrm{N}_{\mathrm{t}}\right)$ \\
\hline 82.190 & 0.053 & 0.034 & 0.854 & 0.026 & 5.211 & 0.004 \\
\hline
\end{tabular}


the life cycle of polymer products has shown that energetic use of them in the post-use phase allows for the recovery of nearly $40 \%$ of the energy required for the production of products and processes that enable the use of packaging and post-consumer waste from these products. The liquid polymer depolymerisation product can be used as a synthetic fuel not only to power boilers adapted to the combustion of liquid fuels (mazut, fuel oil), but also as a fuel to power diesel generators.

5. Despite the low value of the efficiency index obtained, the recovery of energy from plastic waste unsuitable for material recycling should be considered as a positive action.

6. The increase in interest in the process of depolymerisation of plastic waste is the result of increased requirements in the scope of obtaining recovery and recycling levels of plastic packaging waste. Catalytic cracking can be qualified for packaging waste recovery processes, if its products are used energetically. In the settlement of the achieved level of recycling plastic packaging waste, it is not possible to take into account the waste subjected to cracking, as a result of which a mixture of hydrocarbons is obtained. Pursuant to the Waste Act, only recycling is accounted for as recycling of plastic packaging waste, which leads to the creation of a product made of plastic.

\section{REFERENCES}

1. Czaplicka-Kolarz K., Burchart-Korol D. and Korol J. 2013. Application of life cycle and exergy analysis for environmental assessment of selected polymers (in Polish). Polimery 2013, 58, nr 7-8, 605-609.

2. Goedkoop M., Oele M., de Sch A. and Vieira M. 2008. SimaPro Database Manual - Methods library. Netherlands: PRé Consultants. Available: http:// www.pre.nl/download/manuals/DatabaseManualMethods.pdf. Accessed 30 November 2010.

3. GUS (Central Statistical Office) 2018. Environment protection 2018 (in Polish). Zakład Wydawnictw Statystycznych, Warszawa.

4. Kruszelnicka W., Bałdowska P., Tomporowski A., Piasecka I. and Mroziński A. 2018. Analysis of energy benefits of grinding energy carriers (In Polish). Inżynieria i Aparatura Chemiczna, 1/2018, 7-8.

5. Lewandowska A., Szulżyk-Cieplak J. 2018. Analysis of the effectiveness of the municipal waste man- agement system on the example of the Lubelskie Voivodeship, in: Contemporary problems in the field of environmental engineering and architecture (in Polish), red. Czyż Z., Maciąg K. Wydawnictwo Naukowe Tygiel sp. z o.o., Lublin.

6. Marczak H. 2014. Simulations of the influence of changes in waste composition on their energetic propertirs. Journal of Ecological Engineering, vol. 15, nr 4, 90-97.

7. Matuszewski J. 2012. Environmental Impact Report - Zakład Przetwórstwa Tworzyw Sztucznych in the town of Szwecja, commune Wałcz (in Polish). Available online: http://bip.gminawalcz.pl/ dokumenty/403

8. Matynia T. 2011. Method of catalytic cracking of organic waste compounds, catalyst for cracking catalytic waste organic compounds and device for cracking catalytic organic waste compounds (in Polish). Matynia Tadeusz Przedsiębiorstwo „Faber”, Lublin. Polska. Opis patentowy 208361 B1, WUP 04/11.

9. Notice of the Speaker of the Sejm of the Republic of Poland of February 22, 2019 regarding the publication of a uniform text of the Act on the management of packaging and packaging waste (in Polish) (Dz. U. 2019, poz. 542), p. 28.

10. Regulation of the Minister of the Environment of December 14, 2016 on the levels of recycling, preparation for re-use and recovery by other methods of certain municipal waste fractions (in Polish) (Dz. U. 2016, poz. 2167), p. 3.

11. Regulation of the Minister of the Environment of December 3, 2018 on annual levels of recycling of packaging waste from households (In Polish) (Dz. U. 2018, poz. 2306), p. 2.

12. Skutera D. 2013. Research on grinding processes and susceptibility to grinding of porous polyolefins in the aspect of their secondary processing (In Polish). UTP, Bydgoszcz.

13. Spath P.L., Mann M. and Kerr D.R. 1999. Life Cycle Assessment of coal-fired power production. No. NREL/TP-570-25119. National Renewable Energy Laboratory. Golden, Colorado. Available: https://www.nrel.gov/docs/fy99osti/25119.pdf

14. Resolution No. 88 of the Council of Ministers of 1 July 2016 on the National Waste Management Plan 2022 (in Polish) (M.P. poz. 784). Warszawa.

15. VDI 1997. VDI-richtlinie 4600: Cumulative Energy Demand, Terms, Definitions, Methods of Calculation. Verein Deutscher Ingenieure, Düseldorf.

16. Witkiewicz A., Czech R., Zabochnicka-Świątek M., Czech P. and Turoń K. 2018. Transportation of municipal waste on the example of a selected city of the Silesian agglomeration - part 2. Means of transport and costs (in Polish). Autobusy 2018, 12, 1012-1019. 